\title{
A Decolonial Perspective on Boko Haram's Campaign of Terror, Sources of Funding, Mobilisation Strategies and Major Attacks since $\mathbf{2 0 0 9}$
}

\section{Makhura Benjamin Rapanyane Florence Ramasela Sethole}

Department of Political Studies and International Relations

North-West University, South Africa

\section{Florence Ramasela Sethole}

Department of Cultural and Political Studies, University of Limpopo, South Africa

\section{DOI - https://doi.org/10.35293/srsa.v43i1.339}

\section{Abstract}

In the West African region, one conflict that has ravaged the nations since 2009 is the Boko Haram Insurgency which is located in Nigeria. This Islamist group is indisputably the most dangerous group confronting Nigeria today with their violent activities ranging from political and socio-economic to security and governance aspects. Boko Haram has managed to wipe out thousands of Nigerians since its inception in 2009, with an attempt to take power from the legitimate government of Nigeria. Boko Haram's ethnic, religious, and regional fault-lines do not only impact Nigeria but people beyond the borders of Nigeria. A quick review of the current ongoing scholarly debate on the activities of Boko Haram reveals that scholars have not paid much attention to the group's funding, recruitment, and major attacks in combination for better apprehension when reading. In cases where such has been analysed, it has been individually analysed and most of these studies are five-ten years old. Hence, such information needs an update to remain relevant in cases where they are still poised to be relevant. Therefore, this article's central objective is to analyse the three identified themes using a decolonial perspective. It argues that Boko Haram's ongoing campaign of terror is inextricably linked to the funding it continues to receive and strong recruitment tactics.

Keywords: Conflict, Boko Haram, funding, major attacks, historical development 


\section{Introduction}

Before any further reading of this article, the authors have hastened to highlight that the relevancy of the geographical scope of Boko Haram stems from the belief that African conflicts elsewhere in the regions have an immense effect on all other regions inclusive of the Southern Africa. Therefore, through many multifaceted studies on the subject concerned, the authors have been able to identify some of the themes which deserve more scholarly debate and update. The same scholarly themes which pillared this research article have been gauged out from the literature analysis provided below to show exactly what drove the undertaking of this research article.

Firstly, the study of Falode (2016) is extensively acknowledged as it provides a number of strategic responses employed by the government of Nigeria in its attempt to counter-fight Boko Haram. But then left out a deep critical reflection of who funds Boko Haram. The same method of analysis was applied secondly by Obaji (2013) whose study revealed to us that videos, blogs and Youtube are used by Boko Haram which continues to encourage extreme vilification of the enemyother motivating for the holy war through martyrdom.

Thirdly, is the study of Obah-Akpowoghagha (2016) which reveals that Boko Haram continues to feed on the social and economic un-wellness of Nigerians. Human security analysis seems to be dominant as he adds that average citizens do not get enough socio-economic security in Nigeria due to their ongoing battle with cultural deformity, poverty, unemployment, and social discontent amongst the populace. But they did not really pay too much attention to a deep critical reflection of historical major attacks carried out by Boko Haram. The same is also noted from the study of Barna (2014) who has focused on the rise of Boko Haram which continues to contribute to the growing insecurity in Nigeria. $\mathrm{He}$ argued that the growth of Boko Haram is mostly attributed to its main appeal to the unemployed youth that is not satisfied with the actions of the government by employing preaching sessions that promote sedition against the Nigerian government, Christians, and other moderate Muslims. There is also the study of Shuaibu and Saleh (2015) which traces the historical genesis of the Yan Tatsine riots, often interpreted as the predecessor of Boko Haram. They both show that the former leader was Muhammed Marwa (nicknamed Maitatsine), a former controversial leader and Nigerian preacher who used to castigate the Nigerian State. 
As much as it was important to revisit the studies highlighted above, it remains critical to indicate that Marwa was worried about purifying Islam against westernization and modernization and the establishment of a modern state. His brand of Islamic extremism depicts the worst form of anti-Kano and government emirate texts which led ultimately to the formation of religious riots which killed thousands of people in Nigeria in the 1980s. Against this backdrop, the problems of ethnoreligious unrests in Nigeria have of recent times (Boko Haram period) become a subject of considerable attention. This is because of their escalation which continues to move from the West African region to the South, East and North Africa to beyond the continental borders. It is also important to highlight that Nigeria remains a multi-religious country which has been a victim of recurrent deadly religious riots since independence up to today. This happens most in the Northern region of Nigeria such as in the Adamawa, Borno, Yobe, Kaduna, Sokoto, Kano, and Plateau. Hence the undertaking of this article sought to explore Boko's Haram historical roots, its sources of funding, how it mobilizes youth and major attacks it carried since its inception in 2009.

The aim of this article is to analyse Boko Haram's ongoing campaign of terror, sources of funding, recruitment strategies and major attacks since 2009. The objectives of this article are as follows: to explain the historical development of Boko Haram; analyse Boko Haram's source of funding and mobilization strategies; and to analyse Boko's ongoing campaign of terror in the form of historical major attacks since the inception.

This article employed a qualitative research approach by utilizing secondary sources of data. Secondary sources were adopted because most of the available literature drawn and incorporated in this subject could never be different from those of the primary sources, which to some extent could have required months for issues involving ethical complications, technical analytic aspects and issues of movement. The secondary sources used were research reports, journal articles, online articles, official documents, books which have been written about this subject. The authors adopted the use of Thematic Content Analysis (TCA) which is explained broadly (step by step) by Anderson (2017) to analyse the entire collected data. The TCA analysed data had ensured the ingredients (credibility, dependability, and confirmability) of all qualitative research methods by employing data triangulation. 


\section{A Decolonial Perspective}

After a critical reflection on the literature review on the subject of Boko Haram, the authors have noted that there are a number of themes which needs scholarly attention. It is within the context of the Islamophobic violence against ordinary citizens of Nigeria that the ongoing scholarly debate on the state of Boko Haram should be critically reviewed. The authors of this article debunked the commanding Western conceptualisations and theories in analysing this group (Rapanyane 2018). By doing this, a decolonial theory was chosen to ground-root this article in order to unmask the problematic Euro-American epistemic basis of the current commanding analysis of Boko Haram. Far from denying that it remains a big African problem which needs Africa's attention, the authors have highlighted the hypocrisies and inconsistencies (In introduction) of Western theories in analysing this organization as an organization which is a by-product of greedy and selfish Africans who do not value themselves (Rapanyane 2019). By highlighting this point, it was deemed significant also to indicate that an emerging decolonial scholars like ourselves needed a strong theoretical and literature premise on the already existing information and/ data (either of Africans, Europeans or Americans). This is far from being a strange act as some scholars of Afrocentricity do draw from existing mainstream theories to sharpen and strengthen their scholarly debates. It is important to note that as much as this research article was a desktop one, drawing information from secondary sources indeed assisted the article's decolonial authors to achieve the central objectives which have been identified and deemed significant to address.

Indisputably, the advocates and/ prominent decolonial scholars such as Ndlovu (2013) and Ndlovu-Gatsheni (2013), Zondi (2016) and Lushaba (2015) do agree that decolonial scholars find common ground in viewing the issues of Africa as having received negative analysis in the past and negative light in the global march forward. They are supported by Mignolo $(2005,6)$ who argues that "Coloniality is a name for the 'darker side' of modernity that needs to be unmasked because it exists as 'an embedded logic that enforces control, domination, and exploitation disguised in the language of salvation, progress, modernization, and is good for everyone." It was Mignolo $(2005,159)$ who differentiated decoloniality from other prevailing critical social theories and said 
that it is "its locus of enunciations and its genealogy- which is outside Europe." He further indicated that "decoloniality can be best understood as a pluriversal epistemology of the future - a redemptive and liberators epistemology that seeks to delink from the tyranny of abstract universals". We therefore, borrowed the Afro-Decolonial analytic categories of grounding, orientation and perspective from Asante (1990, 2003) and Shai (2016) to sharpen our decolonial epistemic standpoint in this article. This was done with the purpose of justifying the much-required scholarly epistemic intervention from non-Euro-American scholars in order to interject the Global Southerners' perspective and space in re-conceptualising Boko Haram as a by-product of the ongoing funds which are poured into its activities (Copeland 2013).

One important point to note in most theoretical underpinnings is that theories are chosen for a particular reason. In this article, the authors have adopted a decolonial perspective because most of the studies which have been conducted on this subject have subscribed to Non-African, Western theories which have not really been aligned well to the ground-conditions of Africa. These theories often produced western informed experiences on what is transpiring in Nigeria, particularly as it relates to Boko Haram (Rapanyane, 2019). Drawing from this unfairness in the analysis of the subject of this nature, the authors have opted to use a decolonial perspective in order to decolonize this subject so that readers (in the present and the future) can finally hear the genuine voices of an Africans on this subject. Often times, theories of this kind are adopted to bring about an epistemic justice in subjects that lack African decolonial voices. It is within the parameters of the capable African scholars who have an immense interest in ensuring that their voices are heard in African Scholarship to ensure that they analyse these African issues fairly, without taking sides, as they are also informed by African principles of knowing. This stands a good chance in intensifying the struggle for decolonization in Africa.

As much as scholars can disagree to agree that Boko Haram might/might not be a problem of the entire African continent. What remains critical is that Boko Haram developed out of Africa and continues to affect African countries even beyond the borders of Africa. Countries like Chad, Cameroon, Mozambique, and Niger are not sparred in the continued violence that erupts in the presence of Boko Haram. Thus, even if it is still very much predominant in North-Eastern Part of Africa, it continues to be a thriving international terrorist group which 
is beyond control. This means that African scholars should not move away from placing more attention on this group in order to assist in the complete defeat and removal of this group from the African soil. In doing so, this helps Africa in its developmental objectives that are at times, tempered due to the ongoing political instabilities caused by the likes of Boko Haram.

In order to realise the central objectives of this article, the authors present the disentanglement of Boko Haram as a difficult issue in the conceptualisation of the Euro-American complexity involved in trying to analyse the organization as well as their theoretical failures insufficiently explaining Boko Haram, its history, funding and how it mobilizes the youth which continues to join the organisation, and major attacks as shown by these scholars: Falode (2016), Obaji (2013), Shuaibu and Saleh (2015) Barna (2014) and Obah-Akpowoghagha (2016). This move has assisted the authors in epistemologically and theoretically achieving the central purpose of this decolonial article. The first section of this article explores a synopsis of the historical developments of Boko Haram. The next section then deals with sources of funds, mobilization strategies and major attacks of this group.

\section{Boko Haram's historical development in Africa's Western Region}

Boko Haram as it is now first begun as Shabaab Muslim Youth Organisation in the year 1995, with operations in Maiduguri (Borno State Capital), and was led by Abubakar Mallam Lawal. Later on, Lawal decided to make an educational trip to Saudi Arabia and left Mohammed Yusuf in power. Their aim "People committed to the propagation of the prophet's teaching and Jihad" has remained a local Salafist Islamic sect for way too long in Nigeria (Courtin 2015). The word Boko Haram means Western education is forbidden. The Boko Haram group has for long been misguided as it was taught that interaction with the societies of the west was a sin in their Islamic teachings. At the same time, they are opposed to the orthodox Islamic Scholarship (Bartolotta 2011). The Leadership of Yusuf delivered political influence and national popularity to the group (BBC News 2016). After his expulsion from the Muslim clerics of Maiduguri, Yusuf then began his misinterpreted Islamic teachings of falsifying the radical views of Islam through the establishment of a complex Islamic religious group in the Markaz. The same Markaz complex included an Islamic school and a mosque which was 
attended by Nigerian Muslims and neighbours who had an interest in it from Cameroon, Chad and Niger (Thurston 2018). Yusuf in his school and mosque taught a conservative theology that misinterpreted the Saudi-Style Salafism and instructed his followers to disregard the Nigerian secular government (Copeland 2013).

Salaf in simple terms means the devoted people from the past generation of the Islamic community devotees who are the fellows of Mohammed the Prophet and their followers. This composes of the first three Muslim generations and those who managed to follow their ways and belief system (Shuaibu and Saleh 2015). The concept Salafi da'wah signifies a 'call'. Practically, it means calling to the preaching, truths and propagation of pure Islam which is unconfined from alterations, additions, and deletions. In simple terms, it means a strong endearment to the Prophet's path and the true-hearted and strong believers of the previous generations of the community of Islam and a combination of all those who followed them, their beliefs, morals, and actions (Al-Salafi 2015). BBC News (2016) believes that beyond the frontage of Islamic education, Yusuf planned to formulate an Islamic counter-legitimate state through the imposition of the Sharia Law. This is because Yusuf's centre had transformed over time to be the domain of the radicalisation of young women and men. Maybe if the government deployed a sufficient intelligence gathering by its security operatives, Yusuf would not have established his religious Centre. Copeland (2013) has indicated that despite forming a farm and mosque, Yusuf's group imposed a violent form of the Sharia Law which was enforced by its own established police force, anathema to the federalism system of governance employed by Nigeria.

Yusuf's early warning sign of militant or Jihadist tendencies became prevalent when he was suspected to might have killed his former Mentor Sheikh Ja'afar Moh'moud Adam who he accused of disagreeing with on the doctrinal issues (Hassan and Ibhrahim 2007). Adam (who preached in the Maiduguri as a moderate preacher) disagreed with Yusuf on radical and extreme interpretations of Islam. After Adam's assassination, then begun the prolonged kidnappings, bombings, destructions of mosques and churches including the violent attacks on different Nigerian communities, are traced back to the clash amongst the members of the government security officials and the sect in Borno State in the year 2009. This was because of the new legislation by the government of Borno State which forced motorbike riders to wear helmets when riding their bikes on 
the road (Meral 2018). Not, only did members of the Boko Haram condemn this during a funeral procession, but they also carried out attacks against the police force members of the Nigerian government which transmuted into numerous group injuries and deaths (Friedman 2014).

After the direct police clash with members of the Boko Haram sect in 2009 which saw a number of deaths, Murtada (2013) alleges that Yusuf then saw this as a threat and embarked on a Jihadist approach against the State of Nigeria. In response, he wrote an open letter "An Open letter to the Federal Government" in which he described what would transpire in (Jihadi) operation of which he indicated categorically that only Allah would have the power to stop it (Thurston 2018). It was only when the open letter was avoided by the central government of Nigeria that Yusuf took a decision to unleash violent group attacks on the establishments of the government including on security operatives. Murtada (2013) further deliberates that on the $28^{\text {th }}$ of July 2009, the Army of Nigeria attacked the mosque and compound of Yusuf in Maiduguri. Whilst this was taking place, it resulted in the deaths of about 1000 people from the clash of the security forces, army, and the Boko Haram groups, all in Maiduguri (Courtin 2015). In a matter of days, the Maiduguri incident escalated through killings and riots to the members of the sect in Yobe, Kano and Jigawa State of the Northern region. However, Yusuf did not get away as he got caught by the army in Maiduguri to be placed in police custody and died in what is explained as the extra-judicial killing (Courtin 2015).

Copeland $(2013,03)$ has indicated clearly that proceedings over the next several days after the arrest of Yusuf culminated into the gun battles, explosions which were led by the police to besiege Boko Haram sites. This did not go well as police officers were also killed and about 50 buildings destroyed of which many of them included churches and schools. The Nigerian government did set an example with the number of those it captured and executed in what was termed extrajudicial killing and illegal by the Human Rights Watch (HRW) as they were believed to be militants. Murtada (2013) gives us a clear picture of the re-grouping of Boko Haram under the leadership of Abubakar Shekau who replaced Yusuf. Shekau was also mistaken to have been assassinated by the Nigerian army in the years 2010, 2011 and 2012, but kept repeatedly reappearing in the mentioned years on YouTube declaring himself an alive, competent and strong leader of Boko Haram (Obaji 2013). In his first reappearance, Shekau 
declared his baiting sympathy by indicating that Boko Haram's attention was now placed on the security personnel whom he was now declaring a fight on. $\mathrm{He}$ also indicated that Boko Haram was now going to fight Christians and the government security personnel (Obaji, 2013, 24).

He further addressed Christians and alluded that:

You Christians should know that Jesus is a servant and prophet of God. He is not the son of God. This religion of Christianity you are practicing is not a religion of God-it is paganism. God frowns at it. What you are practicing is not religion. Aside from that, you Christians cheated and killed us to the extent of eating our flesh like cannibals!

And also added that:

We follow the tenets of the Quran and anybody that thinks he can fight God shouldn't think his prayer or pray in the mosque can save him! Any Muslim that cheats and hides under the cloak of religion, if we know such person, we won't hesitate to eliminate him. Yes, I am saying so because it doesn't take 5 minutes to kill just as we're being killed. We follow the teachings of the Quran. This is what God has told me to explain. Alhamdulillah! (Obaji 2013, 24-25).

Shekau's regrouping of Boko Haram really resulted in the killing of over 20000 citizens of Nigeria, Chad, and Cameroon wherein which the group has cells. The affected number of people range from 2-6 million people with more than 300000 refugees due to internally displacement (Murtada 2013). Shekau was only replaced in the year 2016 by Abu Musab al-Barnawi who is believed to be the son of Yusuf (founder of Boko Haram) (Busari 2016). In the next section, the authors have decided to redirect attention towards the revelation of the sources of funds which Boko Haram continues to acquire.

\section{Sources of Boko Haram Funding and how it mobilizes the Youth}

Copeland (2013) reveals that most of the initial activities of Boko Haram are funded by the wealthy Salafi Donors whom which Yusuf met whilst on Hajj (Annual Islamic pilgrimage to Mecca, the holiest city of Muslims in Saudi Arabia). The report of terrorist funding in West Africa by the Financial Action Task Force 
(2013) has revealed that Boko Haram is funded through the myriad and private sources. Through this, they are able to exploit the emerging advanced technology to transfer and collect funds. Levitt and Jacobson (2008) also attribute:

The evolution in financing sources to rapid globalization and sustained technological advances, which have enabled terrorist groups to raise, store, transfer, and distribute funds for their operations with ease. In particular, the advent of new technology has spurred changes in how money is transferred, with mobile and online money transfers becoming more commonplace.

After this, Boko Haram is then able to welcome funds from its initial international funders through money transference modes. Financial Action Task Force (2013) report has added that the Boko Haram group receives money through criminal citizen kidnappings and drug trafficking. It is also further alleged in the report that Boko Haram taxes communities under its control through ransom payments for the release of some of the captured foreign or local victims.

Copeland has presented this significant data as the Horn of Africa Desk officer representing the Civil-Military Fusion Centre (CFC) which is the knowledge and information organisation that focuses on the improvement of civil military interaction, information facilitation, enhancement and sharing situational awareness via the civic web portal combined with their monthly and weekly publications. All data is premised upon primary source information from several research centres, organisations, and media sources (Copeland 2013). Whilst on the other side, the Financial Action Task Force remains an independent intergovernmental organisation that develops and promotes regulations and/ policies for the protection of the global financial system against terrorist financing, money laundering, and the Weapons of Mass Destruction (WMD)'s proliferation. The organisation's recommendations are recognised globally on counter-terrorism financing and anti-money laundering standard.

The group survives on captivating unemployed, young, and underprivileged people who are not satisfied with the governance state in Nigeria. It also engages in utilizing the Islamic preachers who advance sedition against the people and government of other moderate Muslims and faiths in for recruitment. Based on both Shuaibu and Saleh (2015), Boko Haram recruits through the 
use of kidnapping underage children ranging from 15-30 who then join the radicalisation preaching and employ suicide bombings as servicemen and women and at some point, executioners through the Jihadist or Islamic groups including the likes of Al-Qaeda, Taliban and Al-Shabab. It is argued that the high rate of unemployment, illiteracy and mis-preaching of Islam are all utilized by Boko Haram to tempt people into joining the sect. Onuoha (2014, 5-7) says that the US Institute of Peace in Tandem in collaboration with Nigerian CLEEN Foundation in 2013 conducted a study on why do youth join Boko Haram and discovered that:

Ignorance of religious teaching opposed to violence makes youth more vulnerable and susceptible to recruitment; Unemployment and poverty make youth vulnerable to radicalization; Children with difficult upbringings are more vulnerable to extremist views; High levels of illiteracy linked to youth radicalization and extremism; Widespread corruption conducive to recruitment and radicalization

Were strong contributory causes of youth willingly joining Boko Haram to radicalise themselves through extremist groups like Al-Shabaab and Al-Qaeda. Indisputably, with these recruitment strategies, there are some Islamic preachers and Imams who lecturers or conveys messages through prayers and gatherings of Muslims. These messages negate propaganda on extensive religious Islamic teaching and bad narrative on the corrupt and weakness of the government (Onuoha 2014). Every time, these preachers engaged in the promotion of hate speeches against government buildings, Christians, and government officials inclusive of other moderate Muslims who are opposed to their religious doctrines. However, the current scholarly discourse on this subject to some extends lend a hand in the exploration of how children of underage are willingly becoming suicide bombers of the group. Most of which are untaught of the destruction and death they are obligated to unleash to the general citizens (Onuoha 2014). The reality of the matter is that Jihadi or the Boko Haram conflict has cost many lives in Nigeria, including billions of dollars when it comes to the purchasing of ammunitions and damaging infrastructures and killing thousands of security operatives in continued sect-security operative clashes. 
During the group's earlier stage of development, especially in the years 2009 and 2010 respectively, Boko Haram utilized hit and run, guerilla tactics, shooting targets on moving motorcycles (McMaster 2018). They have also utilized knives swords, machetes and clubs, locally manufactured mandate weapons and guns. Falode (2016) interjects that through their violent activities, they have managed to attract the international attention of the global Islamic Jihadi groups like AlQaeda to formulate links with. By doing this, Boko Haram sought to enhance its weaponry and expertise system in order to execute well synchronised and bloody thirsty attacks on Nigerian citizens. After this, it then started using improved explosives (IEDs), bombs, the surface to air missiles, rocket-propelled grenades, deadly ammunition, and vehicle monitored machine guns with anti-aircraft visor it currently possesses. Falode (2017) has added that international support from these groups has increased its countrywide sophistication to carry out more coordinated attacks. Also, since it pledged loyalty to the Islamic State (I.S), the qualities of their audio and video productions published on social media has tremendously improved.

\section{Major Attacks by Boko Haram}

This section discusses all major attacks of Boko Haram since 2009. There are a lot of violent attacks that Boko Haram carried out. But the outlined, were deemed major by the authors. They therefore deserve to be explored as they have caused a lot of pain for the affected people. This is so because they took many lives.

\subsection{Bauchi Prison Attack In 2010}

On September 8 2010, there was a manhunt in Nigeria after an eye-catching jailbreak of more than 700 prisoners inclusive of the fancied members of the Taliban (Nossiter 2010). The Nigerian Police reported that four prison guards were shot dead after the Boko Haram Members of the Islamist sect attacked the Bauchi Jail in the North of Nigeria, setting parts on fire and smashing locks. To add, Smith (2010) helps us understand through a Bauchi resident who illustrated how "About 50 men with machine guns came to the prison site, forced the prison open and released all the prisoners." 


\subsection{The 2011 Attacks on the Police Headquarters and the United Nation's beadquarters in Abuja}

In June 2011, Boko Haram bombed the Nigerian police headquarters in Abuja (Capital City). They did this through a car laden that drove into the Louis Edet house compound carrying explosives. It was reported that the driver intended on placing the car near the stairway entrance to target the senior offices but was, unfortunately, redirected towards the back of the building by the security guards where in which the bomb was detonated in the car park (Walker 2012). Again, in August 2011, a Boko Haram man drove a car into the compound of the United Nations (UN) in Abuja and set the detonation of the massive bomb which took about 23 lives and wounded thousands more (Murray and Nossiter 2011). This attack has led Boko Haram to be onto the global news to establish it as a militant group that possess doctrinal, technical and capacity to produce suicide bombs. At a later stage, Boko Haram produced a martyrdom video which was filmed by the car driver (Walker 2012).

\subsection{Bombing in Kano and 2014 Chibok Secondary School 300 Girls Kidnapping}

On April 30 2012, Boko Haram again carried out attacks at the University of Nigeria's Northern City of Kano which caused a stampede through the firing of shots and explosives. BBC News (2012) understand that: "For over 30 minutes a series of bomb explosions and gunshots took over the old campus, around the academic blocks," which killed more than 180 people and this has since remained its deadliest attack to date. On the night of 14-15 April 2014, Boko Haram again went on a rampage to kidnap 276 girls from the Chibok Village of Northeastern Nigeria. The Boko Haram militants carried out this kidnapping by storming the school out (Melvin 2015). They were accompanied by convoys of buses and trucks to engage in gun battles with security guards of the school. After defeating the guards, they then forced the girls into the trucks and drove into the forest. Many of these girls were never seen again except some in photographs sat on the ground in clad whilst wearing Islamic dresses in semi-circles (Oduah 2014). It is often emphasised that those who did not escape continue to be victims of rape, 
brutality, enslavement, and conversion to Islam.

5.4. 2015 Baga shootings, 2000 killed and the 2019 funeral procession Attacks

On the 12th January 2015, Boko Haram carried another violent attack in what is described as also the deadliest massacre on the Baga village where they left thousands of bodies scattered all over the place (Estimation of 2000 dead). It was reported that upon their arrival, they uploaded motorcycles and sprayed bullets all over the residents who then ran into the bush (Abubakar and Karimi 2015). Bukar Musa (Former Chairman of the Local government) in Buga said that "Dead bodies litter the bushes in the area and it is still not safe to go and pick them (up) for burial," and "Some people who hid in their homes were burned alive." (Abubakar and Karimi 2015). On 29th July 2019, at least 65 Nigerians were left dead during an attack by Boko Haram on a funeral gathering in northeast of the country. This took place in the Nganzai District just next to the Borno State. Boko Haram shot dead about 21 people first and others were shot dead when villagers were running after the assailants. Others were injured critically (Busari, Abrak \& Sherry, 2019). This incident took place right after the same group forced an estimated 30000 people out of the country in January 2019 (Adebayo and Mazloumsaki 2019).

\section{Conclusion and recommendations}

In the final analysis, one may ask how this article was decolonial. The only answer to this is that this article has been written by an African decolonial scholar with the intention of bringing a decolonial scholarly awareness of all activities involving Boko Haram. The decolonial part stems from the belief that Boko Haram even in the previous other studies has been studied using other mainstream theories. Thus, the current article is a by-product of the epistemic location which has been adjoined with our intent to contribute to the current decolonial scholarship on African political discourse.

The authors sought to bring a decolonial awareness to the sources of the ongoing violent activities of Boko Haram in Nigeria. To this far, the authors have been able to trace the historical genesis of Boko Haram to the times of the leadership of Yusuf who was replaced by Shekau and now it is commanded by 
Yusuf's son al-Barnawi. This article has also shown that the activities of Boko Haram owe historical starting point from the misguided teachings of Islam by Yusuf to some of the people who affiliated to his former Shabaab Muslim Youth Organization. This is the same group which turned more and more extreme, Islamic and violent over time until it officially became Boko Haram which carried out violent and deadly attacks especially in the Northern region of Nigeria. This article has also revealed that Boko Haram's continued operations are funded by wealthy Salafi Donors who were first drawn by Yusuf during Hajj back in 2009. Al-Shabaab and Al-Qaeda are also some of the international funders of Boko Haram and they have managed to bring more attention to Boko Haram after their established strong network. Despite this, Boko Haram has carried a number of violent and deadly attacks on the citizens of Nigeria. Amongst those identified which are major include the 2009 Bauchi Prison attack, 2011, Police Headquarters attack in the Federal Capital Territory, 2011 attack on the United Nation's headquarters in Abuja, 2012, Bombings in Kano, 2014 Kidnappings of 300 from Government Girls Secondary School Chibok, 2015 Baga shootings which results in deaths over 2000 and 2019 Funeral procession attack.

From a decolonial point of view, it is indisputable to state categorically that in just over a decade, this group has advanced from being a local Salafi Islamist organization in Nigeria's North-Eastern parts to now an international violent terrorist organization that carries out kidnappings, killings, bombings and destruction of mosques, churches, government properties and telecommunication equipment in Nigeria and other parts of Western Africa. It remains a growing terrorist intimidating remark due to the ongoing strong feed from its recruitment strategies and sources of funding which remains in bulk. That is why Nigeria, Niger, Cameroon and Chad (four Lake Chad nations) have joined forces to establish a joint military force to counter-fight this growing international Jihadist organization. This is a particular new decolonial discovery as most of the previous studies have only analysed individual themes and provided solutions. The inextricable link has been much shortened and often not understood well.

Recommendations: Nigeria and the countries affected by Boko Haram insurgent group should engage those who are financing Islamic Jihadist group and negotiate with them to stop the continued financing of this violent and deadliest extremist organization. Equally important, the Nigerian Army and Police officers should start patrolling around girl schools which are most vulnerable to the 
attacks of the members of Boko Haram. This will help in ensuring that those who intend on carrying out violent attacks on these girls or kidnapping them think twice before they engage in such missions. The Nigerian government should also stop corruption and start redirecting the public funds towards the creation of employment opportunities for the youth who are at most, vulnerable to joining this group. The African countries through the African Union (AU) peace and security architecture should find it in themselves to assist with either peacekeeping troops to the region in order to assist those soldiers who are an army on a mission. The ongoing violent attacks on government buildings can only be stopped if Boko Haram fined it within their means to engage their Nigerian government and try to settle their differences peacefully without having to resort to violent measures.

\section{References}

Abubakar, Aminu, and Karimi, Faith (2015). 2,000 feared killed in 'deadliest' Boko Haram attack in Nigeria.. https://edition.cnn.com/2015/01/09/africa/bokoharam-violence/ (accessed 03 16, 2020).

Adebayo, Bukola, and Mazloumsaki, Sara (2019) 30,000 Nigerians flee Boko Haram violence in two days, UN says. 2019. https://edition.cnn.com/2019/01/29/africa/ nigerians-flee-boko-haram-violence-intl/index.html (accessed 03 13, 2020). As-Salafi, Abu' Iyad. (2015) The Principle of Salafiyya, A Brief Introduction to the Salafi Dawah. http://www.salafipublications.com/sps/ sp.cfm?subsecID=SLF02\&articleID=SLF020001\&articlePages=1 (accessed 03 12, 2020).

Anderson, Rosemarie. (2017) Thematic Content Analysis (TCA): Descriptive Presentation of Qualitative Data.. www.rosemarieanderson.com (accessed 03 10, 2020).

Asante, Molefe Kete. (2003) Afrocentricity: The theory of social change. Chicago: African American Images,.

Asante Molefe Kete (1990) Kemet, Afrocentricity and Knowledge. Trenton: Africa World Press,.

Barna, Judit. (2014) Insecurity in Context: The Rise of Boko Haram. European Parliament: Police Dept, Director General for External Policies,. 
Bartolotta, Christopher. (2011) Terrorism in Nigeria: The Rise of Boko Haram. The White head Journal of Diplomacy and International Relations. 9.

Busari, Stephanie. (2016) Boko Haram's new leader is son of executed founder, insider says. 2016. https://edition.cnn.com/2016/08/04/africa/nigeria-boko-haramleader/ (accessed 03 10, 2020).

Busari, Stephanie, Abrak, Isaac, Sherry, Sophie and Goyette, Braden (2019). Suspected Boko Haram attack on a funeral leaves 65 dead in Nigeria, official says.. https://edition.cnn.com/2019/07/28/africa/boko-haram-attack-nigeria/index. html (accessed 03 11, 2020).

BBC News. (2016) Who are Nigeria's Boko Haram Islamist group?. https://www.bbc. com/news/world-africa-13809501 (accessed 03 14, 2020).

Copeland, Foard (2013) The Boko Haram Insurgency in Nigeria.Civil-Military Fusion Centre.Comprehensive Information on Complex issues.. Foard.Copeland@ cimicweb.org. (accessed 03 12, 2020).

Courtin, Nicolas. (2015) Understanding Boko Haram. Afrique contemporaine 3 (255): 13-20.

Falode, James Adewunmi. (2016) The nature of Nigeria's Boko Haram, 2010-2015: A Strategic Analysis." Perspective on Terrorism 10 (1): 41-52.

Financial Action Task Force. (2013) fatf report terrorist financing in west africa. . http://www.fatf-gafi.org/media/fatf/documents/reports/tf-in-west-africa.pdf (accessed 03 14, 2020).

Friedman, Uri. (2014) The Bike-Helmet Law That Helped Trigger an Insurgency in Nigeria.. https://www.theatlantic.com/international/archive/2014/05/the-bikehelmet-law-that-triggered-an-insurgency-in-nigeria/371301/ (accessed 03 10, 2020).

Hassan, Karofi, and Ibhrahim, Yasha'u (2007) Nigeria: How Sheikh Ja'afar Was Killed - Eye Witnesses.. https://allafrica.com/stories/200704170726.html (accessed 03 14, 2020).

Levitt, Matthew, and Jacobson, Michael (2008). The Money Trail: Finding, Following, and Freezing Terrorist Finances. Washington DC, United States.: Washington Institute for Near East Policy,.

BBC News. (2012) Deadly attack on Nigeria's Bayero university in Kano.. https:// www.bbc.com/news/world-africa-17886143 (accessed 03 15, 2020). 
Lushaba, Lwazi Siyabonga. (2015) Theoretical Reflections on the Epistemic Production of Colonial Difference. University of the Witwatersrand, Johannesburg: PhD thesis.

McMaster, Geoff. (2018) The scourge of Boko Haram is far from over. https://www. folio.ca/the-scourge-of-boko-haram-is-far-from-over/ (accessed 03 09, 2020).

Melvin, Don. (2015) Boko Haram kidnapping of 200 Nigerian schoolgirls, a year later. https://edition.cnn.com/2015/04/14/africa/nigeria-kidnapping-anniversary/ index.html (accessed 03 09, 2020).

Meral, Ziya. (2018) How Violence Shapes Religion: Belief and Conflict in the Middle East and Africa. Cambridge: Cambridge University Press,.

Mignolo, Walter (2005). The Idea of Latin America. Malden, MA: Blackwell Publishing,.

Murray, Senan, and Nossiter, Adam (2011). Suicide Bomber Attacks U.N. Building in Nigeria.. https:/www.nytimes.com/2011/08/27/world/africa/27nigeria. html?auth=login-email\&login=email (accessed 03 04, 2020).

Murtada, Ahmad. (2013) Boko Haram in Nigeria: Its Beginnings, Principles and Activities in Nigeria.. http://salafimanhaj.com/ (accessed 03 13, 2020).

Ndlovu, Morgan. (2013) Mobilising History for nation-building in South Africa: a decolonial perspective. Yesterday and Today 9: 1-12.

Ndlovu-Gatsheni, Sabelo (2013) Perhaps decoloniality is the answer? Critical reflections on development from a decolonial epistemic perspective. Africanus 43 (2): 1-12.

Nossiter, Adam. (2010). Prison Raid in Nigeria Releases Hundreds. https://www. nytimes.com/2010/09/09/world/africa/09nigeria.html (accessed 03 05, 2020).

Obah-Akpowoghagha, Nelson Goldpin. (2013) Theoretical Underpinning of Conflicts and Violence in Nigeria: The Niger Delta Militant \& Northern Islamic Sect, Boko Haram in Perspective." Public Policy and Administration Research 3 (10): 69-77.

Obaji, Konye. (2013) Conceptualizing Boko Haram: Victimage Ritual and the Construction of Islamic Fundamentalism. Indiana University: Unpublished Masters Research Report,.

Oduah, Chika. (2014) Chibok: the village that lost its daughters to Boko Haram.. https://www.theguardian.com/world/2014/may/15/chibok-nigeria-200kidnapped-schoolgirls-boko-haram (accessed 03 05, 2020). 
Onuoha, Freedom. (2014) SPeCIAL RePoRt: Why Do Youth Join Boko Haram?. https://www.usip.org/sites/default/files/SR348-Why_do_Youth_Join_Boko_ Haram.pdf (accessed 03 14, 2020).

Rapanyane, Makhura Benjamin. (2019) An Afrocentric exploration of Jacob Zuma's anti-Apartheid stance: The question of Israeli-Palestinian struggle. Journal of Public Affairs/ Early View. 2 (2): 1-8

Rapanyane Makhura Benjamin. (2018). South Africa's foreign policy towards Israel within the context of the Palestinian question, (1999-2018). Mankweng, University of Limpopo: Unpublished Hons Mini-Dissertation,

Shai, Kgothatso Brucely. (2016) An Afrocentric critique of the United States of America's foreign policy towards Africa: The Case studies of Ghana and Tanzania, 1990-2014. Mankweng, University of Limpopo: Phd Thesis,.

Shuaibu, Salisu Salisu, and Saleh, Mohd Afandi (2015). Historical Evolution of Boko Haram in Nigeria: Causes \& Solutions. University Sultan Zainal -Abidin. Malaysia: Proceedings of ICC 2015,.

Smith, David. (2010) More than 700 inmates escape during attack on Nigerian prison .. https:/www.theguardian.com/world/2010/sep/08/muslim-extremistsescape-nigeria-prison (accessed 03 10, 2020).

Thurston, Alexander. (2018) Boko Haram: history of an African Jihadist Movement. Princeton and Oxford: Princeton University press,.

Walker, Andrew. (2012) What Is Boko Haram?. https://www.usip.org/sites/default/ files/resources/SR308.pdf (accessed 03 10, 2020).

Zondi, Siphamandla.(2016) A Decolonial turn in Diplomatic Theory: unmasking epistemic injustice. Journal for Contemporary History 41 (1): 18-37. 